\title{
Forgotten shelters of Kłodzko Land. On architecture inspired by the local building tradition
}

\author{
Jacek Suchodolski \\ Chair of Architecture and Visual Arts; Faculty of Architecture; Wroctaw University of Science and \\ Technology; ul. B. Prusa 53/55, Wrocław, Poland; \\ jacek.suchodolski@pwr.edu.pl (iD)0000-0002-4767-6169
}

\begin{abstract}
The article addresses the problem of the decline in the number of tourist facilities with outstanding features of regional architecture, built before 1945 in Kłodzko Land. Their destruction is an irreparable loss for the cultural heritage of the described region. Usually designed in the spirit of the local building tradition - born out of centuries of experience of the people living here - hostels, inns and taverns were a characteristic, regional distinguishing feature of the landscape of Kłodzko Land. Meanwhile, the new architecture of objects related to tourism, built after the end of the Second World War, most often does not refer to the characteristic forms and structures of local buildings. The article stresses the need to put an end to the often deliberate practice of destroying old pre-war buildings and to draw the attention of architects working today to the importance of continuing local, regional forms in the emerging tourist facilities.
\end{abstract}

Keywords: architecture, shelters, Kłodzko Land

\section{Introduction}

Kłodzko Land, partially covering the areas of the Central and Eastern Sudetes, is certainly one of the most diverse and interesting regions in the Sudetes in terms of tourist attractiveness. The reasons for that are its history, a significant number of architectural monuments, including wooden buildings in the regional style, and the landscape diversified by the ranges of the Stołowe, Orlické, Bystrzyckie, Bardzkie, Bialskie and Golden Mountains, as well as the Śnieżnik Mountains, the Kłodzko Valley and the Upper Nysa Rift. What nature created here in the form of an undoubtedly attractive landscape has been used by man for centuries, i.a. in tourism: in developing new maps, setting out hiking trails, buildings shelters, inns and viewpoints.

The second half of the nineteenth century brought a lot of investments in the Sudetes, related to the expansion of railway routes and roadways accompanying the mining and textile industry emerging here, as well as glassworks, porcelain factories and other types of 
production. This had a major impact on the development of tourism, which also became one of the profitable branches of the economy. A more important and clearly visible element of tourism development, which also constitutes a form of its architectural expression, were the emerging shelters and other tourist facilities, more and more of which were built on mountain slopes and in valleys in the Sudetes, and thus in Kłodzko Land, providing travellers with accommodation and rest.

Unfortunately, the period of development of these lands and the expansion of tourist facilities in the Sudetes was interrupted in 1945, after the borders were changed. Lower Silesia became a part of Poland, and settlers from various parts of the former Commonwealth of Poland came to replace the current German population; however, they were not usually familiar with the specificity of farming in the mountains. To make matters worse, Poland found itself in the zone of Soviet influence, which meant that a command-and-distribution economy was established, which is a denial of logical and established principles in economics. Moreover, uncertainty prevailed among settlers whether the decision to annex the Western Territories to Poland would last or not. It was often used by the authorities as leverage in the event of social unrest. All these factors did not favour stabilisation, especially in the initial period after the end of World War II. As a consequence, many tourist and leisure facilities were devastated and liquidated, including those with significant value of the architectural and regional features they represented.

\section{Aim of the study}

The aim of the study is to restore and preserve the memory about those tourist shelters which had an interesting regional form and constituted an important part of the cultural landscape of Kłodzko Land before 1945. These buildings should become an inspiration for contemporary architects in order to restore the cultural continuity of this region and to create new architecture, enriched with traditional elements. The current article presents and publicises this problem in an attempt to halt the process of degradation, which consists in decapitalising and then demolishing the objects from before 1945. It should be the task of institutions established for this purpose, mainly the Provincial Heritage Monuments Protection Office in Wrocław, because these objects are often valuable examples of old, unique work of local builders. The above-mentioned examples are only a fragment of what was irretrievably lost in Kłodzko Land after the end of the war and in later years. This problem concerns the entire range of the Sudetes on the Polish side of these mountains.

\section{Tourist and sport resorts in Kłodzko Land}

Over the past centuries, three main centres of tourism and winter sports were formed in Kłodzko Land, in which most of the buildings with recreational and tourist functions were concentrated, including shelters, mountain inns and taverns. These include the Śnieżnik Mountains, whose name is derived from the highest mountain in the former Kłodzko County $-1425 \mathrm{~m}$ above sea level - along with summer resorts and famous winter resorts such as Międzygórze and Sienna with the ski resort in Czarna Góra, and Jodłów, Potoczek or Goworów [18], situated slightly away from Śnieżnik. The following one is Masyw Orlicy $-1084 \mathrm{~m}$, located in the Orlické Mountains - with Zieleniec, Kozia Hala, Graniczna and Podgórze, which are now parts of Duszniki-Zdrój [17]. The third mountain massif, whose first ascent, in 1790, is one of the earliest known, [13], [19], is Szczeliniec Wielki (919 m) located in the Stołowe Mountains, with the adjacent Karłów, Karłówko and Pasterka. 
In addition to the main resorts, there were also smaller ones, in which tourist and recreational architecture was constructed, including well-known buildings [15]. Among others, towns on the Dzika Orlica River should be mentioned here: Lasówka, Piaskowice, Mostowice, Rudawa, Poniatów, Niemiów and Lesica. Sudeten huts with an interesting regional form [17], [24], [25] were also located in Spalona, Wójtowice, Młoty, Biała Woda in the Bystrzyckie Mountains or the Puchaczowska Pass separating the Śnieżnik Mountains from the Krowiarki Mountains. Before 1945, in the above-mentioned resorts and individual towns, as well as in particularly attractive places, such as passes or summits in the mountains, mountain shelters, hotels and mountain inns formed a well-organised system of to urist and recreational facilities, which suffered significant degradation after the Second World War. Places that used to be densely populated became deserted; where buildings once stood, hills covered with grass and trees are now seen - these can be easily identified and stimulate the viewer's imagination even stronger. Out of 56 shelters in Kłodzko Land (Fig. 1) which existed before 1945, as many as 43 are no longer in operation and only thirteen have a tourist function. After the war, only three new facilities of this type were built [4], [13], [16], [25].

\section{Regional architecture as a source of inspiration for the form and architectural details of shelters and inns in Kłodzko Land}

As in the neighbouring ranges of the Sudetes on the Silesian and Czech sides, characteristic features of the local wooden architecture also developed over the centuries in Kłodzko Land. The fact that the Kłodzko County used to belong to the Czech Crown for many centuries is also apparent in the form of its wooden architecture, largely resembling its Czech versions [1], [9], [13], [23]. The most common object of regional origin on both sides of the border is a one-storey building with a log structure of wooden walls and a steep gable roof with a slope of 45-55 degrees. At first roofs were covered with straw or reed thatch, then with wood shingles, less often with phyllite slate. Even before the First World War, in some buildings sheet metal was nailed to shingle roofing through intermediary ridge beams as an external covering, which increased fire resistance, but changed the character of the whole [9], [23] (Fig. 2). 


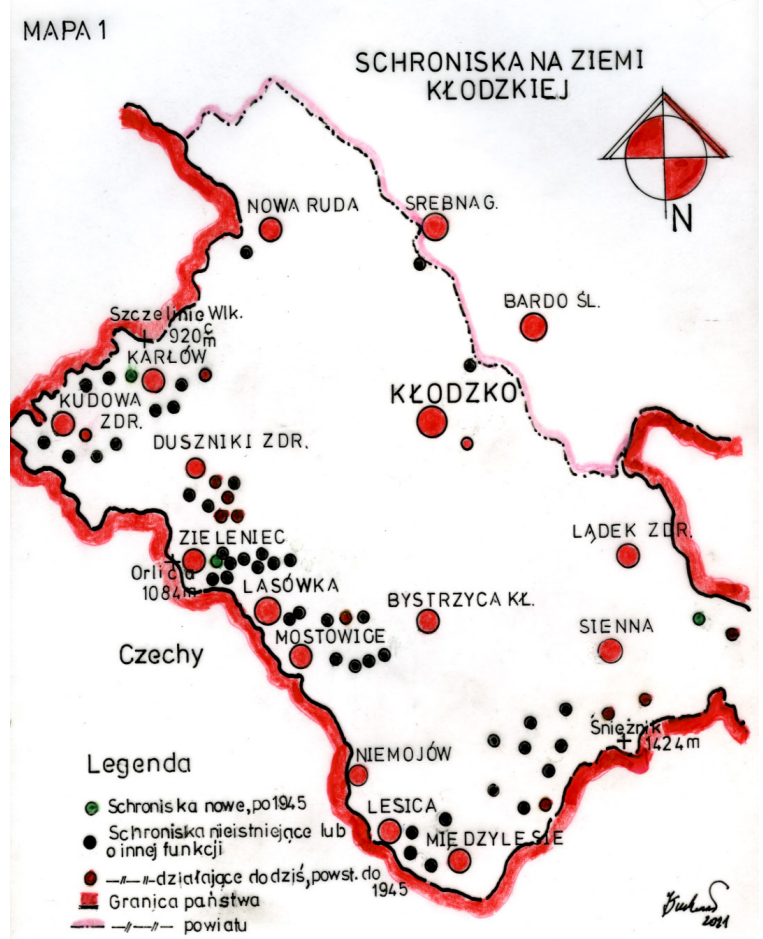

Fig. 1. Location of shelters in Kłodzko Land (points: green - new shelters, built after 1945; black - non-existent shelters, shelters that perform a different function; red - shelters in operation today, built after 1945; lines: red - Polish and Czechia state border; rose - poviat (district) border). Author's study

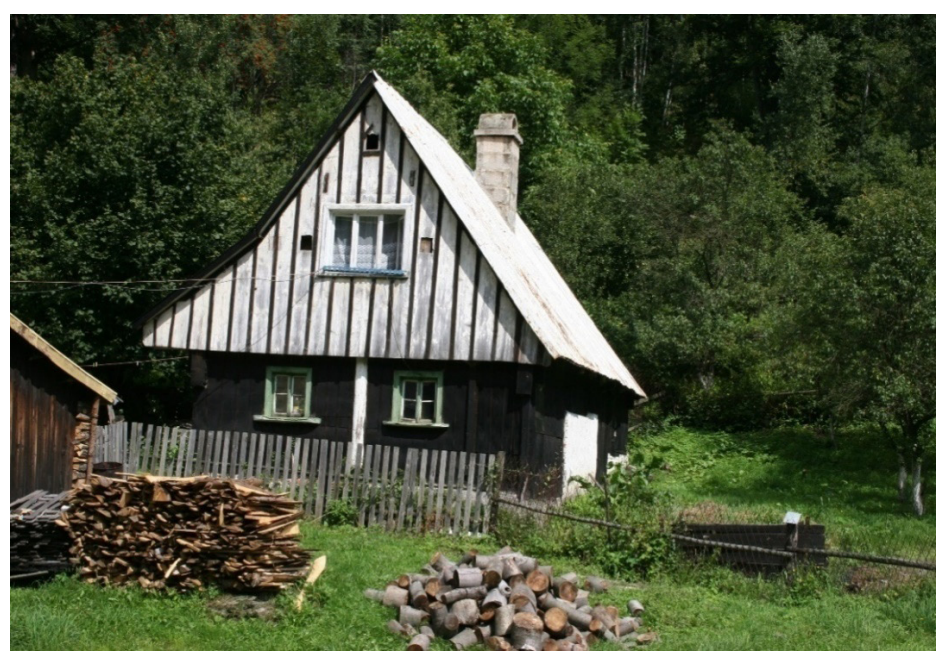

Fig. 2. The village of Młoty in the Bystrzyckie Mountains. A rural residential building with log walls, a gabled roof covered with sheet metal, with a slope of 45 degrees. Photo by Jacek Suchodolski 2005 
Among the varieties of regional architecture, there are also single-storey wooden houses with an attic storeroom, i.e. a single-storey extension in the form of a dormer (extending beyond the perimeter of the building), supported on posts. Known in Polish as wyżka, pięterko or ryzalit wejściowy, it was originally used for storing hay, and over time it became an additional living space for holidaymakers visiting these areas [23] (Fig. 3).

Buildings in the region had gable roofs or roofs with a mansard structure. Buildings with log walls and mansard roofs are also a distinctive group among wooden architecture. Larger in volume, they often had the above-mentioned attic storerooms and served as taverns, shelters and inns. These roofs were mostly covered with diamond-shaped eternit or sheet metal tiles (Fig. 4).

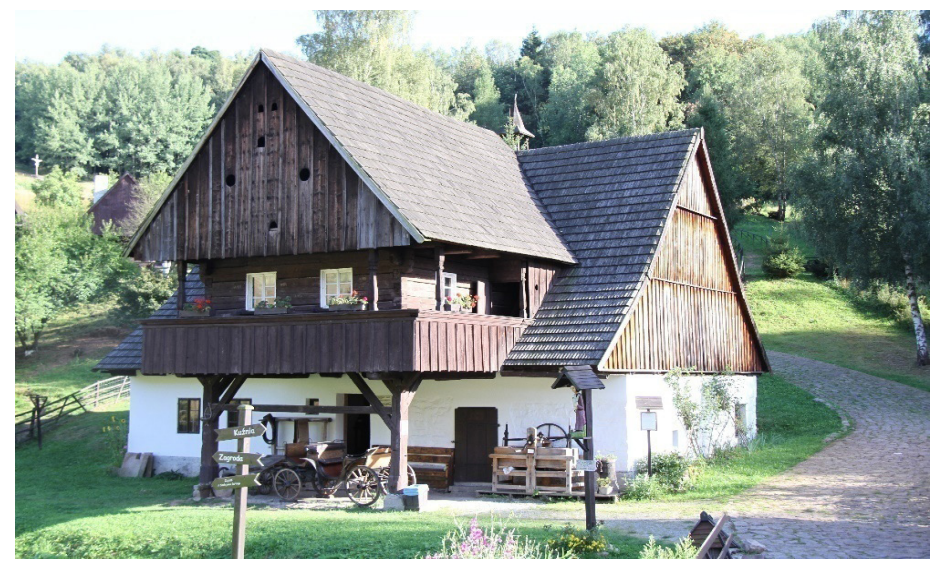

Fig. 3. Pstrążna - an open-air museum of wooden buildings. The so-called Zajazd (Inn) moved from Szalejów Dolny (probably built in the first half of the nineteenth century). The modest form of a single-storey house with $\log$ walls is diversified by an attic storeroom, i.e. an extension protruding beyond the eaves, supported on posts, in which there were rooms for tourists. Photo by Jacek Suchodolski 2015

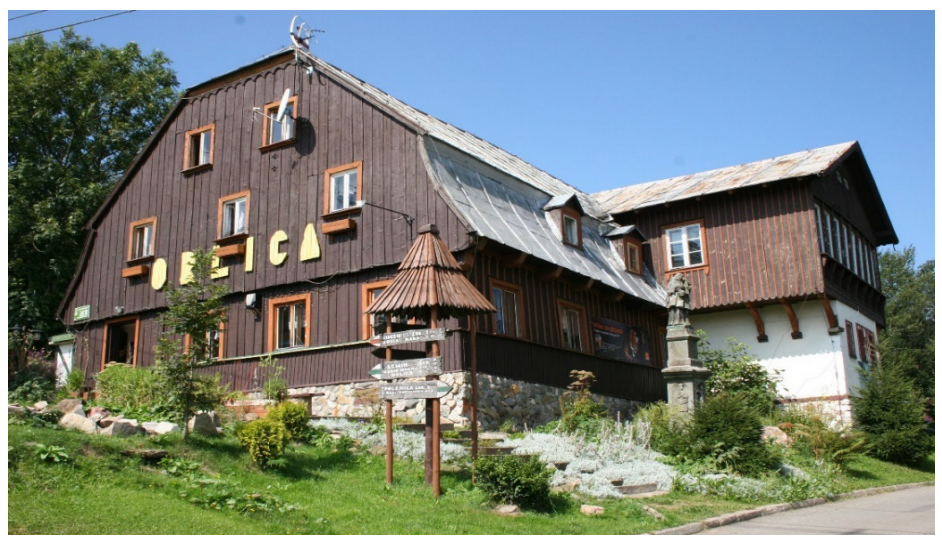

Fig. 4. Orlica shelter in Zieleniec, built in 1878. The building with log walls, covered from the outside with vertically-laid boards and with a mansard roof with dormers, also has an attic storeroom in the form of an extension, supported by the masonry walls of the ground floor. There was a second tavern near Orlica (Gasthaus zur Mense), of a similar shape and structure, but it was pulled down in the 1960s. Photo by Jacek Suchodolski 2009 
An important distinguishing feature of the regional architecture is also the architectural detail which gives it a distinct character and a kind of charm. The most characteristic elements include the arrangement of boards on the side and gable walls, the size and form of window openings and the shape of their trims, door lintels, types of structural joints in the walls and the most common types of roofing. It should be emphasised here that the main feature of regional houses were their proportions - the height of the walls of the ground floor in relation to the height of the roof (ranging from 1:2 or 1:2.5 to 1:3). Buildings intended for tourist purposes, put up in the mountains in the described region, were characterised by form and detail mostly based on regional motifs, and houses that were designed in isolation from local tradition were rare [9], [23].

\section{Non-existent tourist facilities with regional features}

The places where the largest number of tourism-related facilities, i.e. inns and shelters, ceased to exist after 1945, certainly include Zieleniec (Grunwald) in the Orlické Mountains, which is currently a part of Duszniki-Zdrój. Initially a poor mountain village, founded in 1719 , over time it became one of the better known winter resorts with excellent conditions for skiing, as well as for hiking and cycling in the summer, thanks to extensive routes on the Polish and Czech side of the border [14], [25], [26]. Even before the First World War, when it was inhabited by almost 900 people, it boasted many well-known shelters and inns located on the slopes of Šerlich and Orlica, forming small complexes of buildings, scattered over the mountainous terrain. The most famous ones, now non-existent, were Hindenburgbaude, Hohe Mense-Baude, Gasthaus zur Mense (later called Ritterbaude) and Berghof Rübartsch (formerly called Reinerzer "Ski - Hütte"), or Mensehorst am Goldenen Stolen. Also in the central part of Zieleniec there was an inn that gained the rank of a shelter - Grunwaldbaude, whose name was changed in the 1930s to Adlerbaude. In 1948, Hindenburgbaude, built in 1928, ceased to exist. The author of this successful project was Konrad Goebel, a member of GGV and the architect of the city of Kłodzko. GGV was also the investor. Located at an altitude of $975 \mathrm{~m}$ above sea level, at the foot of Orlica, it was characterised by a compact form, inspired by regional architecture. Wood was the basic building material here, both for construction and finishing - apart from the basement walls and fragments of the ground floor made of stone. The skilful combination of the texture of wooden walls with stone elements in the entrance area emphasised the regional character of the building. The huge, steep, gable roof with pediments, covered with shingles, certainly stood out in the body of the shelter. The plan for the functions of the shelter also deserved praise, especially its ground floor with rooms intended for guests, where the designer managed to create interiors with an individual character. Decorated in a regional style with wooden carvings, they gave a sense of solidity and security. There was a fuel dispenser next to the shelter, as it could be accessed by car. Unfortunately, this building burned down in November 1948, probably as a result of a boiler room failure [14], [22] (Figs. 5-7). 


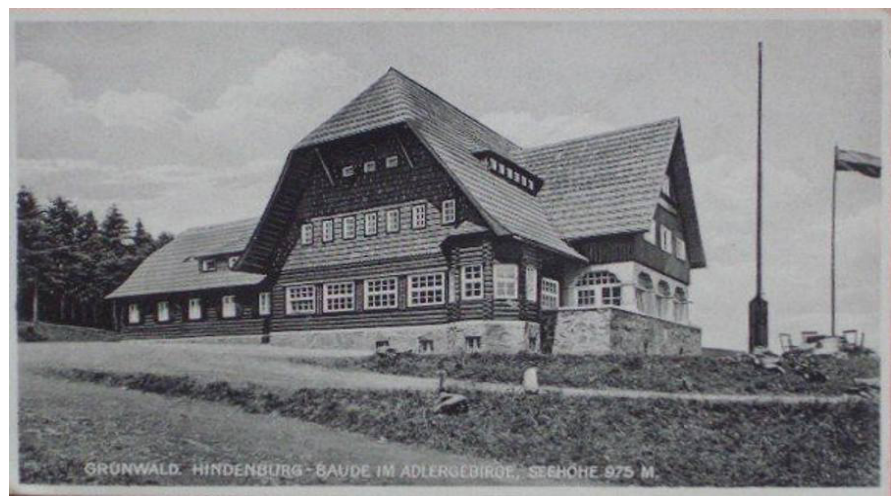

Fig. 5. Zieleniec (Grunwald). Hindenburgbaude shelter. North-east façade. The interwar period. Source: Jacek Suchodolski's collection

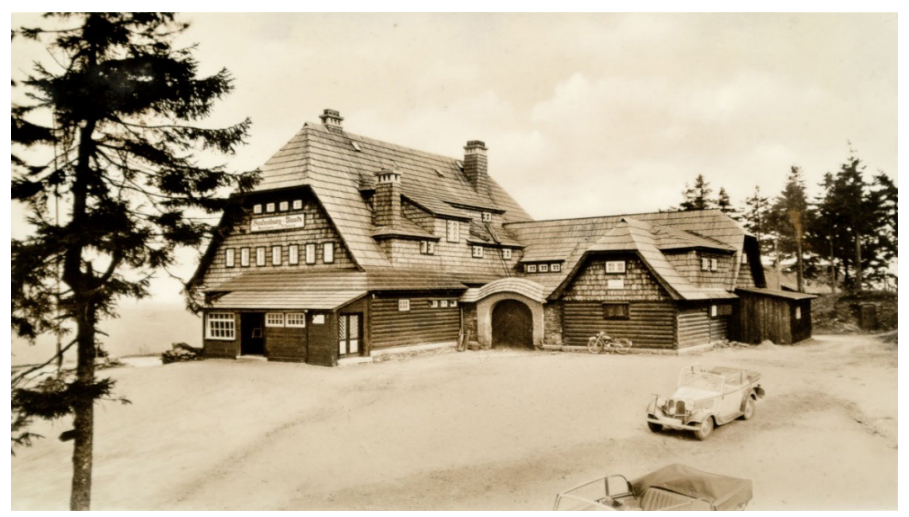

Fig. 6. Zieleniec. Hindenburgbaude shelter. North-west façade. The interwar period. Source: the collection of the Museum of Kłodzko Land in Kłodzko

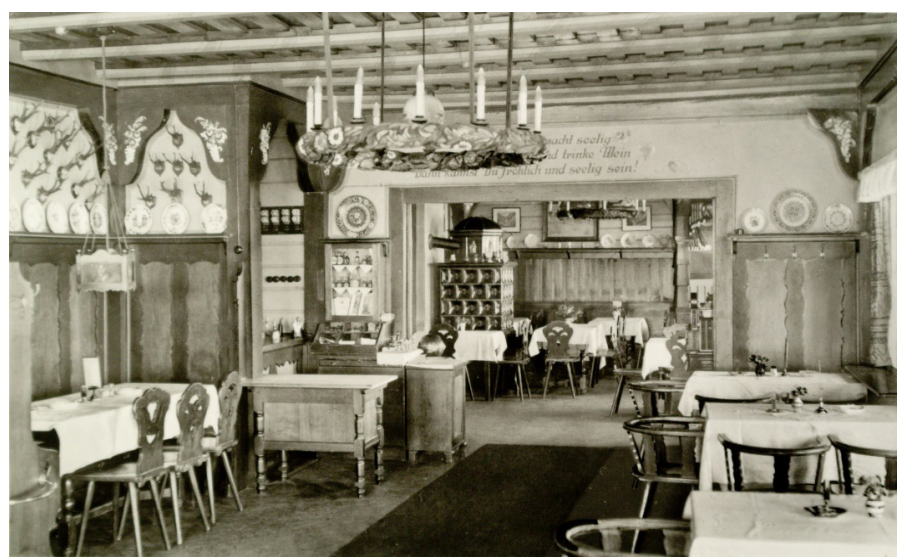

Fig. 7. Zieleniec. Hindenburgbaude shelter. The interior of the dining room. The interwar period. Source: the collection of the Museum of Kłodzko Land in Kłodzko 
This shelter, as it should be emphasised once again, was one of the most beautiful in the Sudetes, alongside Samotnia (Kleine Teichbaude) on Mały Staw in the Karkonosze, and Lucyna (Max Müllerbaude) in the Owl Mountains, which makes its loss even more severe. The second shelter - Hohe Mense-Baude (1084 m) - was built gradually, thanks to the efforts of its owner Heinrich Rübartsch, just below the summit of Orlica, at the Austrian-Prussian border. It was characterised by a simple form, and it consisted of two buildings with log and masonry construction, covered with steep gable roofs, with a wooden observation tower next to it (Fig. 8). They provided rest and accommodation for 10 people in bedrooms and 25 places in a shared room. The main advantage of this place, it seems, was the surrounding nature as well as peace and quiet, which was so valued - especially at the end of his life - by Heinrich Rübartsch, the precursor of skiing in Zieleniec, who contributed to the development and significance of this place in the Sudetes as a tourist resort. When he left the world of the living in 1930, he left behind an equally valuable thing: a memory of a person who never refused to help anyone, sometimes in extreme mountain conditions [24], [26].

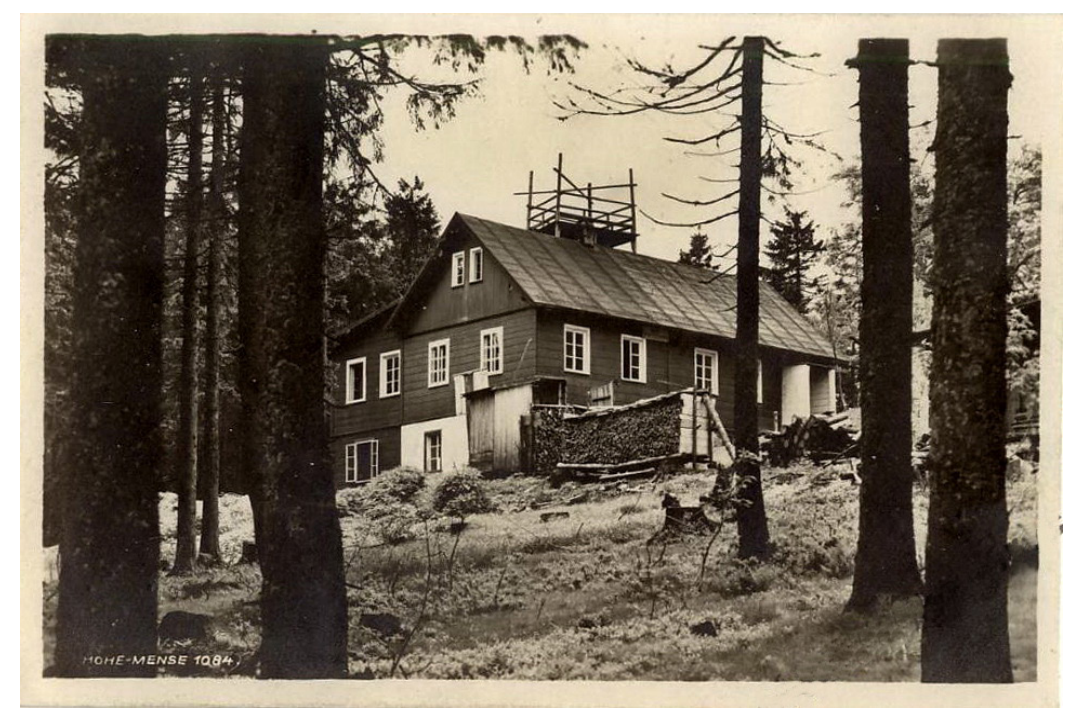

Fig. 8. Zieleniec. Hohe Mensee-Baude shelter. The interwar period. Source: www.ansichtskarten.de

The first shelter building was constructed in 1883, the second in the first years of the twentieth century. The shelter was demolished in the 1940s. The next building, Gasthaus zur Mense ( $872 \mathrm{~m}$ above sea level), is also associated with Rübartsch, because this was where he began his work as an innkeeper. Located opposite the main entrance to the church, the Gasthaus building was one of the oldest in Zieleniec (apart from the wooden church demolished at the beginning of the twentieth century), and its form referred to the regional tradition of wooden architecture of Kłodzko Land. It offered 35 beds in 15 rooms. Gasthaus changed its name to Ritterbaude after it was taken over by a new owner. This one-storey building, covered with a mansard roof with a pediment and an attic storeroom, was one of many objects of this type found on the Kłodzko-Orlické border, as well as in other parts of the region. To a large extent, it resembled the Orlica shelter from 1878 - which still stands next to it - in terms of form and detail, but it was probably older. Rübartsch eventually left Gasthaus zur Mense in 1903, when he moved permanently to his Hohe Mense-Baude shelter at the top of Orlica. After the war, the 
inn building fulfilled auxiliary functions for some time as Orlica III. Gasthaus zur Mense was demolished in the 1960s [24]. Another shelter - Berghof Rübartsch (975 m above sea level) - situated on steeply sloping ground, was a relatively small facility, but had visible regional influences in its architecture. It provided 25 beds. The original name of this Orlické hut on the slope of Šerlich Mountain was Reinerzer "Ski Hütte". After 1945, the building ceased to exist
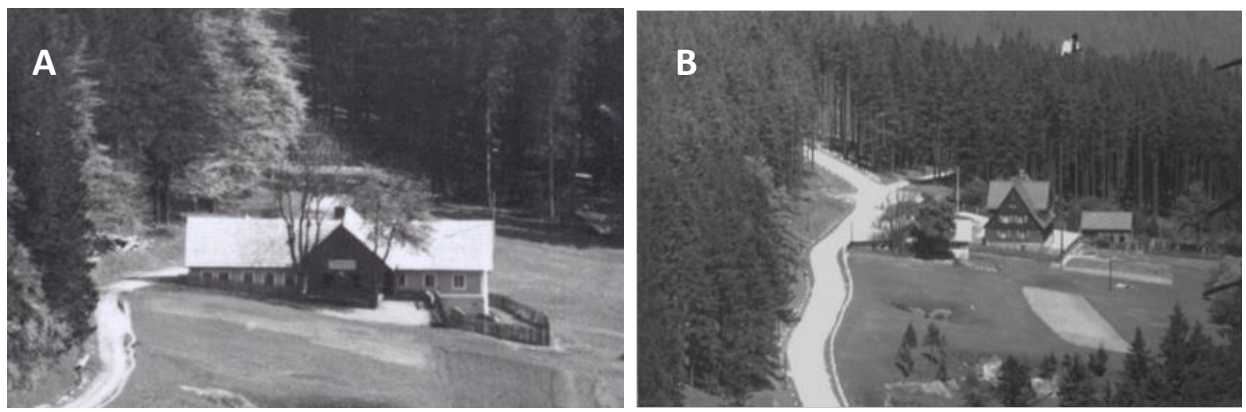

Fig. 9. Mensehorst am Goldenen Stollen shelter: (A) - the first building from 1927, (B) the shelter after its expansion (after 1936). Source: Andrzej Wziatek's collection

Mensehorst am goldenen Stollen youth hostel, located about two kilometres from Zieleniec, by the Orlicka Road, was built in 1927 as a small one-storey building with a steep gable roof (Fig. 8A). It had 23 rooms with 40 beds. In 1936, a second, also one-storey building (Fig. 8B) was erected on the plot of the existing facility, with architecture reminiscent with its form of border guard buildings in many Sudeten towns along the border (e.g. in Szklarska Poręba, on the Okraj Pass, in Jarkowice, Pasterka, Zieleniec, Lasówka, Rudawa, Lesica, Międzylesie). In the 1960s, Mensehorst am Goldenen Stollen was demolished.

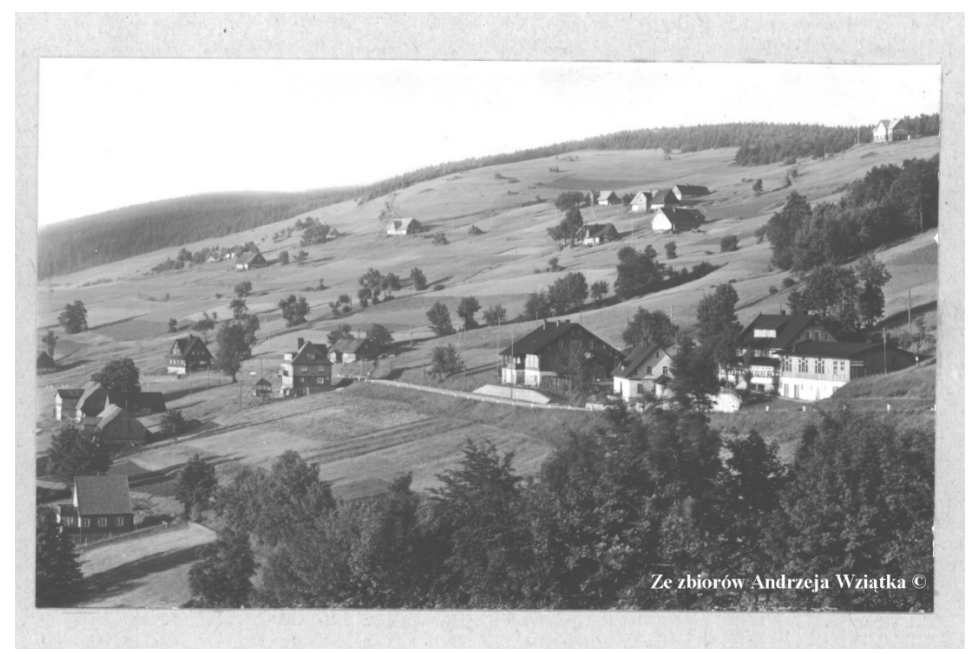

Fig. 10. Zieleniec. In the foreground, on the right, the Grunwaldbaude shelter, later known as Adlerbaude. A characteristic element in the body of the shelter was the observation porch. The interwar period. Source: Andrzej Wziatek's collection 


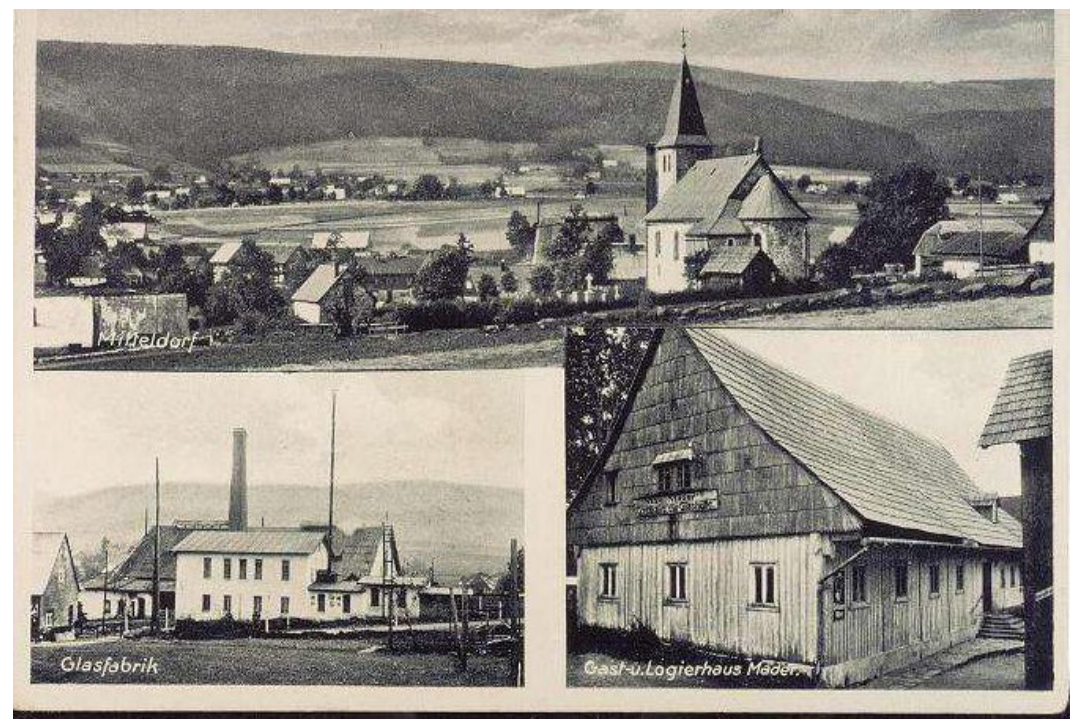

Fig. 11. Lasówka (Kaiserswalde). Three-field postcard, the interwar period. Bottom right corner: Max Mader Gasthaus. This object, which had probably been built in the mid-nineteenth century, ceased to exist in 1954. Source: www.klodzkikatek.pl

The last shelter in Zieleniec from this group, located in the central part of the town, which no longer exists today, was Grunwaldbaude ( $900 \mathrm{~m}$ above sea level), called Adlerbaude since 1934. It had 16 beds. Initially, it was an inn, which then became a shelter (Fig. 10). A porch was added in the 1930s, enlarging this object and giving it a tourist character. The architecture of this Sudeten hut, though it did include some regional elements in its architectural details, did not stand out as anything special. However, the volume of this object was adapted to the surrounding buildings and did not cause visible disharmony, which, unfortunately, is now often seen in the expanding Zieleniec. After the war, in the 1950s, Adlerbaude was renamed Janosikowa Hala, which was then taken over by the Wrocław University of Physical Education and demolished. All the above-mentioned shelters - perhaps the last one the least - had a common quality: namely, their architecture was strongly saturated with local and regional features, which, together with their location in the mountainous terrain (which made them harmoniously fit in with the surrounding landscape), made the panorama of Zieleniec uncluttered and clear. In the neighbouring Lasówka (Kaiserswalde), known before the war for a crystal glassworks and a glass cutting plant, Max Mader Gasthaus (Fig. 11) shelter/inn - a one-storey, wooden building situated next to the church - was demolished in the 1950s. Its form and detail clearly attested to its regional origins, which were evident in such features as a steep gable roof covered with shingles, log walls of the ground floor, covered with vertically-laid boards, and the gable wall covered with shingles. Small window openings with trims represented the modest architectural details of Mader's Gasthaus. As befits the regional Sudeten structures, the ratio of the height of the ground floor walls to the roof height was 1:2. [25] (Fig. 11). 


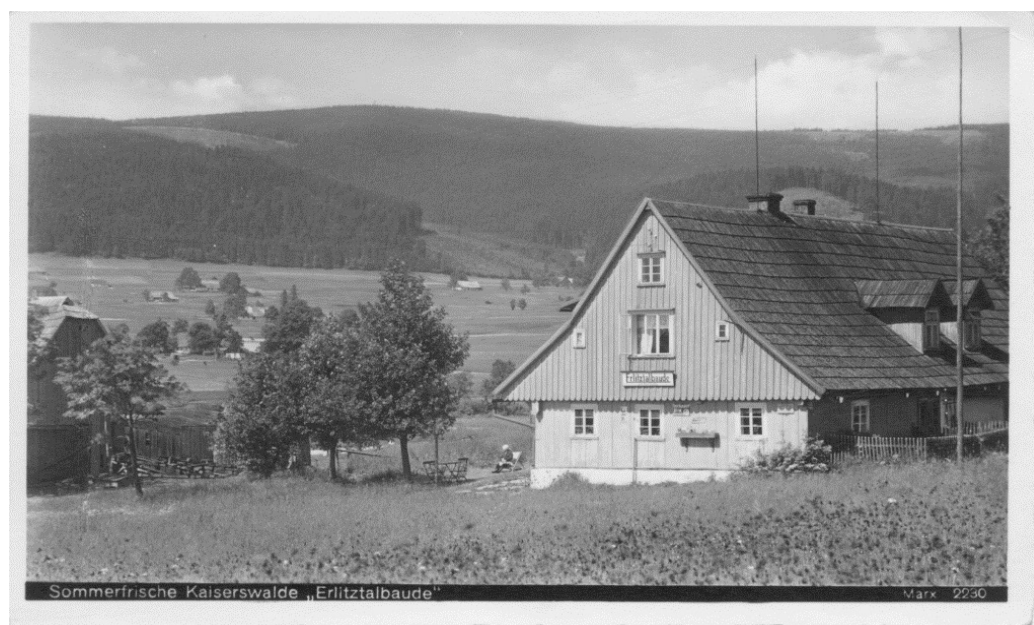

Fig. 12. Lasówka (Kaiserswalde), Erlitztalbaude shelter, the interwar period. Source: Jacek Suchodolski’s collection

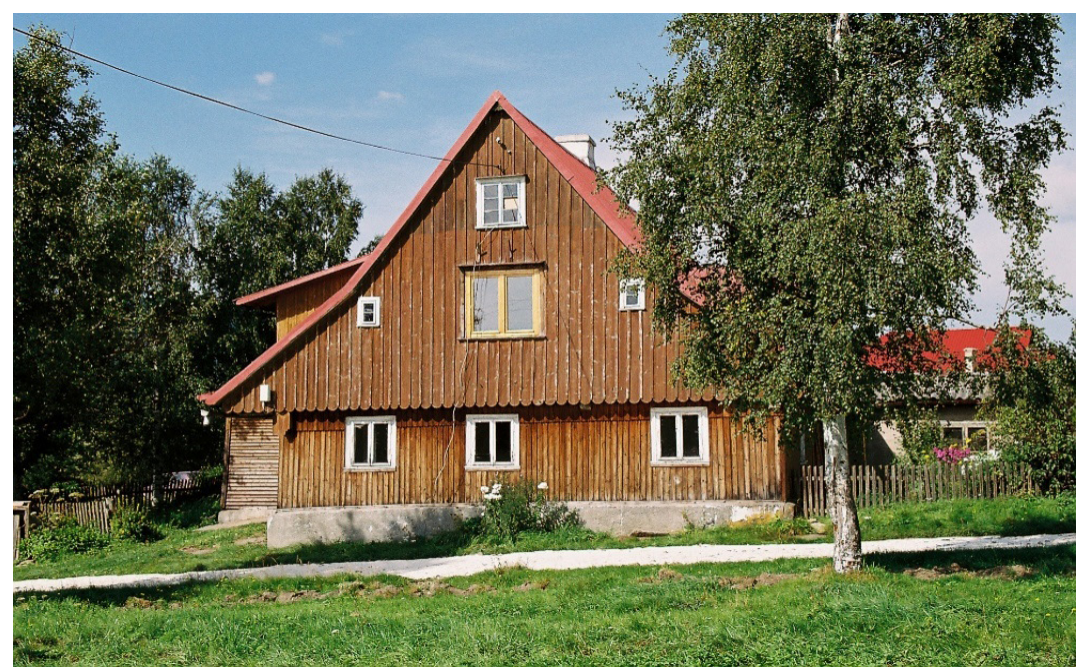

Fig. 13. Lasówka (Kaiserswalde). Former Erlitztalbaude shelter, now a residential building. The metal sheet on the roof was nailed to the original shingle covering through ridge beams. Photo by Jacek Suchodolski 2005

The second shelter, Erlitztalbaude (Fig. 11, 12), located near the Mostowy Stream, which also has a classic, regional form, has survived to our times, becoming a residential building after 1945. Initially, it housed the Stumpfgasthaus inn, and in the 1930s it became a shelter. A characteristic element in the body of the building is the raised roof slope (Frakdach), intended to provide larger cubic capacity in the attic. This was often used in facilities intended for tourist and leisure purposes. This building - like the previous one - represents one of the varieties of the local regional architecture, whose main features 
include log walls of the ground floor, covered with vertically-laid boards, a steep gable roof and small window openings with trims. The proportions of the ground floor walls to the roof height are 1:2. The places from which several inns and shelters also disappeared after 1945 and to which the tourist industry has not returned since were the Waldhufendorf-type village of Lesica (Freiwalde) on the Jelonik stream and the nearby settlement Czerwony Strumien (Rothflössel), located on the stream of the same name, which is, as the former, a tributary of the Dzika Orlica. The hamlet of Lesica, Hirschenhäuser, was characterised by particular landscape values, and it had two inns in the second half of the nineteenth century. One of them was transformed into Hirschenhaus shelter $(650 \mathrm{~m}$ above sea level) with a wooden structure. Above the ground floor with a log wall there was a high, steep roof covered with shingles, which also protected the gable wall against atmospheric influences. The building was representative of one of the varieties of regional construction, often found in Kłodzko Land. After 1945, the shelter ceased to exist. Regional features were also visible in the case of the facility located in Czerwony Strumien, namely Gruppenbaude shelter (which was an SS resort during the war), whose ruins are located at the foot of Bochniak Mountain ${ }^{1}$. Among the well-known shelters with regional architectural features which have not survived to our times, Baude Carl Rast (680 m above sea level) can be mentioned, located near the also non-existent today waterfalls Pośny in the Table Mountains, in Karłówek (Klein Karlsberg), which disappeared after the war. The inn functioning here was transformed into a shelter in the mid-nineteenth century, and then expanded in the first years of the twentieth century. In two wooden buildings, one of which had an attic storeroom, there were 14 beds. After the war, when Pośna waterfalls ceased to exist, which was caused by the creation of the artificial lake in Radków, the shelter fell into ruin. As in other mountain ranges in the tourist county of the Sudetes, there were also buildings in the Table Mountains that until 1945 served as shelters, such as Rabenkoppenbaude (721 m above sea level) in Dańczów, characterised by a classic regional form. After the war they became private residential buildings [25]. In the village of Biała Woda (Weisswasser), located near the Puchaczówka Pass, by the road connecting Bystrzyca Kłodzka, Lądek and Stronie Śląskie, a youth hostel Jugendherberge Weisswasser was built with over 100 beds; its architecture was modelled on regional motifs. After 1945, the shelter ceased to exist. A little above the pass, on the northern slope of Czarna Gora, by the road mentioned above, in the first half of the nineteenth century there was an inn called Puhu Wirtshaus, transformed at the beginning of the twentieth century into the Puhu-Baude shelter (899 $\mathrm{m}$ above sea level). (Fig. 14).

1 Its ruins are marked on the tourist map: Góry Bystrzyckie, Góry Orlickie, scale 1:35 000, Wydawnictwo Compas, Cracow, catalogue number: 1473/2019 [7]. 


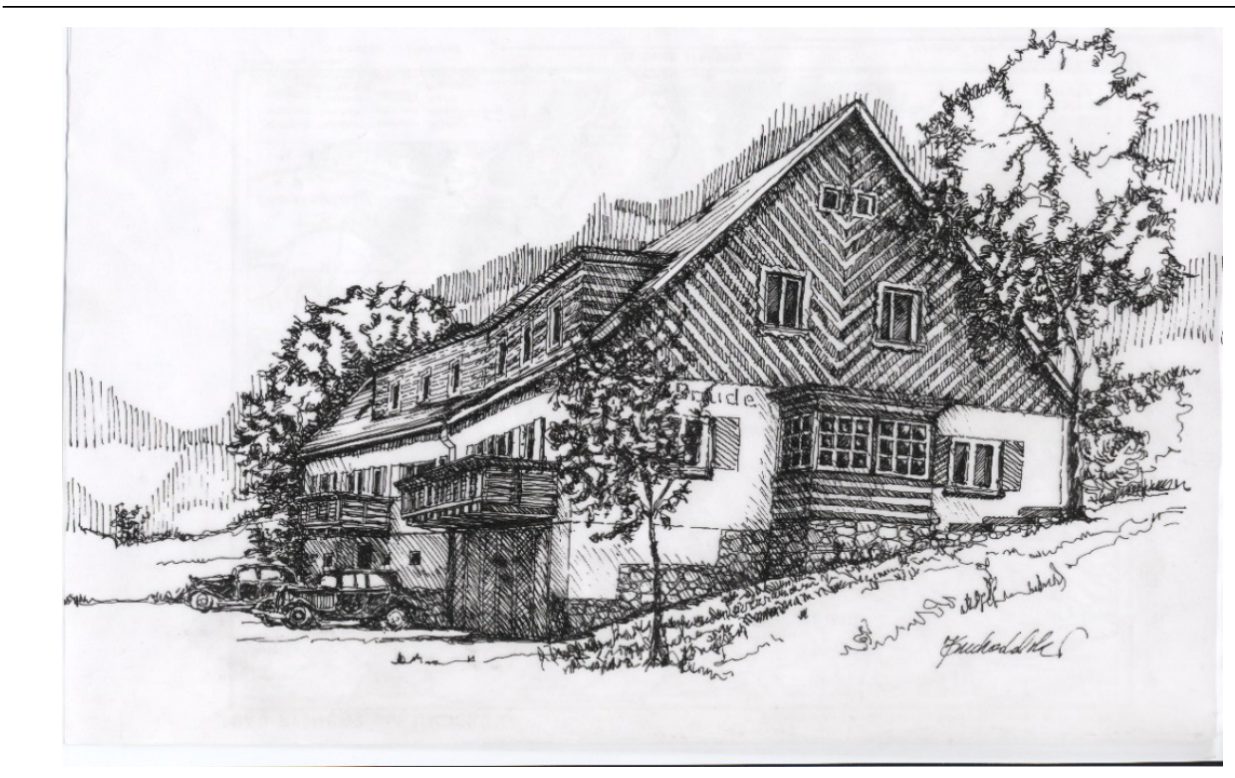

Fig. 14. The Puchaczówka Pass ( $899 \mathrm{~m}$ above sea level) separating the Śnieżnik Mountains from the Krowiarki Mountains. The Puhu-Baude shelter, the interwar period. Drawing by Jacek Suchodolski [17]

Along with the change of the inn into a shelter, it was expanded and its architecture was given a regional form. It had 17 beds in 14 rooms and a shared room. The wooden-brick building gained a compact body with a steep, gable roof with a long dormer. The gable walls were covered with boards arranged in a herringbone pattern, and the ground floor windows were fitted with shutters, which clearly referred to regional motifs. The interior of the shelter was in a rustic style, which was emphasised by the beam structure of the wooden ceiling. Similarly, tables and chairs were made of wood, and it was all complemented by a large tiled stove. White areas between the ceiling beams were covered with floral motifs. Porcelain plates decorated with local motifs hung on the walls, and under the ceiling there was a wooden candelabrum depicting a group of musicians, reminiscent in its form of the works of woodcarvers from the Cieplice school of crafts $^{2}$. This shelter, which was very popular before the war, ceased to exist after 1945. Near Puhu-Baude, another small shelter was built in the interwar years - SchwarzeBerg-Häusel (900 m above sea level), located on the slope of Czarna Góra. An alpine garden was founded around it, the remains of which are still visible today. The building was crowned with a characteristic steep gable roof, giving it a somewhat "fairy-tale" character. Like the neighbouring shelter, Domek Czarnogórski was pulled down after 1945

2 In the School of Wood Carving in Cieplice near Jelenia Góra (Holzschnitzschule Bad Warmbrunn), founded in 1902, which educated both sculptors-artists and craftsmen, a characteristic style was born, inspired by the local folk tradition as well as that of south Tyrol. The school was animated by Cirillo Dell'Antonio (a teacher and later the principal of the school in Cieplice in 1920-1940). The works of the graduates of the school could be found throughout the Sudetes, often in the form of stylised images of groups of people that decorated information boards, signposts or the interiors of shelters [20]. 


\section{Conclusion}

The examples of non-existent shelters in Kłodzko Land described here reflect only a small scale of the problem which was and still is the devastation of the cultural environment after 1945 in these areas as well as in other parts of the Sudetes. Unfortunately, it is especially visible on the Silesian, i.e. Polish side of these mountains. The listed non-existent objects, distinguished by their regional architecture, were an inseparable component of the mountain landscape, currently very incomplete and often further damaged by the foreign form and an inadequate scale of the buildings being erected today, which does not contribute to restoring the cultural continuity of the region. Therefore, it is indispensable to provide professional and systematic conservation care and legal protection over the still existing wooden buildings of regional character, including tourist and recreational facilities, as well as compliance with the provisions contained in detailed land use plans. This has become exceptionally important in recent years, as the volume and form of buildings under construction that serve tourist functions are a contradiction of tradition and often common sense (examples are the Gotębiewski Hotel in Karpacz or the Infinity apartment building in Zieleniec, which is under construction, intended for around 1,000 people). Similar facilities are planned and if these intentions are not stopped by public opinion and competent authorities, the degradation process will deepen. According to the author, in order to restore former splendour and uniqueness to the cultural landscape of Kłodzko Land, one should consider recreating some former shelters and inns in their original locations. This would apply to objects with special aesthetic and regional values of their architecture, i.e. some of those referred to in the article. As it has already been stated, new facilities should incorporate solutions inspired by the local building tradition in their form and structure. Examples of such an approach are residential buildings and those with a tourist function, designed in Alpine areas in Germany, Austria, Switzerland or Italy. Thanks to the use of mainly wood and stone and modest architectural details, the buildings fit in well with the surrounding landscape, at the same time being a contemporary, creative complement to it and its continuation, i.e. they meet the assumptions that should also be implemented in the Kłodzko Region and other parts of the Sudetes in terms of shaping architecture.

\section{References}

[1] Bocheński S., Trocka-Leszczyńska E., Wiatrzyk S., "Architektura regionalna Ziemi Kłodzkiej - tradycja, stan istniejący, możliwość kontynuacji”, Raporty Instytutu Architektury Politechniki Wrocławskiej (PRE series), no. 384, (1986).

[2] Brygier W., Dudziak T., Ziemia Kłodzka. Pruszków: Oficyna Wydawnicza Rewasz, 2010.

[3] Chmielewski W.J., Regionalizm współczesnej architektury reakcją na procesy globalizacji. Cracow: Dział Poligrafii Politechniki Krakowskiej, 2017.

[4] Dziedzic M., "Schroniska Kłodzkiego Towarzystwa Górskiego", Sudety, no. 8, (2009), p. 37.

[5] Dziedzic M., Kłodzkie Towarzystwo Górskie -1945, Wrocław: Quaestio, 2013.

[6] Ferien und Wochenend in der Grafschaft Glatz, Herausgegeben vom Hauptvorstand des G.G.V.. Glatz: Kłodzkie Towarzystwo Górskie, 1932.

[7] Góry Bystrzyckie, Góry Orlickie. Mapa turystyczna skala 1:35000. Catalogue numer: 1473/2019, Cracow: Wydawnictwo Compas, 2019.

[8] Kosiński W., Setkowicz B., "Śnieżnik - organizacja przestrzenna rekreacji”, Turystyka w Sudetach, Prace Karkonoskiego Towarzystwa Naukowego, no. 10, part 2, Jelenia Góra: Wydawnictwo Turystyczne „PLAN”, 1977.

[9] Löwe L., Schlesische Holzbauten. Düsseldorf: Werner-Verlag, 1969. 
[10] Marx J., Vom Schneeberg zur Hohen Eule. Leimen/Heidelberg: Marx Verlag, 1975.

[11] Mazurski K.R., Góry Bystrzyckie i Orlickie, Sudety. Wrocław 1993.

[12] Mazurski K.R., “Schronisko PTTK Orlica”, Na Szlaku, no. 10(136), (2000), p. 19.

[13] Mazurski R.K., Historia turystyki sudeckiej. Cracow: Oficyna Wydawnicza Wierchy, 2012.

[14] Michna W., Zieleniec i okolice. Okruchy historii. 1st ed., Paczków: Wiesław Michna, 2016.

[15] Otto A., Glatzer Wanderbuch. Ein Erinerungsbuch an die Grafschaft Glatz / Schlesien. 3rd ed., Leimen/Heidelberg: Marx Verlag, 1981.

[16] Potocki J., Rozwój zagospodarowania turystycznego Sudetów od połowy XIX wieku do drugiej wojny światowej. Jelenia Góra: Wydawnictwo Turystyczne „PLAN”, 2004.

[17] Stownik Geografii Turystycznej Sudetów. Góry Bystrzyckie i Orlickie. Vol. 14, ed. M. Staffa, Warsaw: Wydawnictwo PTTK Kraj, 1992.

[18] Słownik Geografii Turystycznej Sudetów, T. XIV Góry Bystrzyckie i Orlickie. M. Staff (ed.), Warsaw: Wydawnictwo PTTK "Kraj, - Krakow 1992.

[19] Słownik Geografii Turystycznej Sudetów. Masyw Śnieżnika, Góry Bialskie. M. Staff (ed.), vol. 16, Warsaw: Wydawnictwo PTTK Kraj, 1993.

[20] Bździach K., ed., Wspaniały krajobraz-Artyści i kolonie artystyczne w Karkonoszach w XX wieku. Berlin: Gesellschaft für Interregionalen Kulturaustausch; Jelenia Góra: Muzeum Okręgowe, 1999, pp. 223-237.

[21] Przerwa T., Między lękiem a zachwytem. Sporty zimowe w śląskich Sudetach i ich znaczenie dla regionu (do 1945 r.). Wrocław: Atut, 2012.

[22] Sroka P.,"Hindenburgbaude w płomieniach”, Sudety, no. 113, (2010), p. 29.

[23] Suchodolski J., Regionalizm w ksztaltowaniu formy architektury współczesnej na obszarze Sudetów. Habilitation thesis, Wrocław: Oficyna Wydawnicza PWR, 1996.

[24] Suchodolski J., „Architektura regionalna schronisk i zajazdów w Masywie Orlicy”, Konferencja Kłodzko-Orlicka, Duszniki Zdrój 21-22.04.2005, Biuletyn pokonferencyjny, Nowa Ruda, pp. 47-62.

[25] Suchodolski J., Architektura schronisk górskich w Sudetach. Wrocław: Oficyna Wydawnicza PWR, 2005.

[26] Tomczak M., “Orlica - szczyt zapomniany”, Pielgrzymy'88. Informator krajoznawczy XXXIII Ogólnopolskiego Rajdu Sudeckiego, Wrocław: SKPS, 1988, pp. 77-89. 
